\title{
EMERGING VALUE OF BROWNFIELDS REGENERATION
}

\author{
D. DAMIGOS \& D. KALIAMPAKOS \\ National Technical University of Athens, Greece.
}

\begin{abstract}
Nowadays, it is widely recognized that brownfields revitalization has the potential to promote sustainable growth especially in urban areas. Nevertheless, given that state and local authorities operate within an increasingly tight fiscal environment, brownfields become often of low priority, unless there exist significant human health and ecosystem threats, and remain degraded and underutilized. In order to confront this situation, it is vital for the responsible authorities to justify the necessity of redevelopment projects in 'hard', that is monetary terms. Toward this direction, not only economic but also social and environmental benefits should be monetized by means of market and non-market valuation methods. The paper presents two case studies, the redevelopment of a former metallurgical complex to a Technological and Cultural Park and the potential reuse of the former Athens International Airport as a Metropolitan Park, as a means of highlighting the emerging value of brownfields regeneration. The results indicate that both projects, when examined from a social point of view, create an economic value and contribute significantly toward sustainable development.

Keywords: brownfields redevelopment, market values, non-market values.
\end{abstract}

\section{INTRODUCTION}

Over the past decades, almost all of the world's developed economies have experienced industrial downsizings, shutdowns and relocations due to the rapidly changing conditions in their external environment. In addition, public infrastructure facilities have been left behind, idled or underutilized for political, economic, technical or even social reasons. As a result of this situation, thousands of properties (i.e. former industrial sites, airports, railway stations, etc.), which are commonly known as 'brownfields', have been abandoned. Although the true extent of the problem remains unclear, Oliver et al. [1] under the CLARINET and CABERNET networks provide some figures with respect to the derelict land in some European countries, for example 128,000 hectares in Germany, 65,760 hectares in England, 20,000 hectares in France, 11,000 hectares in the Netherlands, 800,000 hectares in Poland and 900,000 hectares in Romania.

Brownfields cause significant environmental and socio-economic problems, which in turn have also economic implications. For example, the Office of Emergency and Remedial Response (OERR) [2] found that hazardous sites decrease the original property value between 2 and $8 \%$, within a range up to 3-7 miles. Similar results are reported from other studies (e.g. [3-5]). Using a different approach, namely conjoint analysis, Alberini et al. [6] investigated the tradeoffs people of four cities in Italy with severely contaminated sites were prepared to make between income and mortality risk reductions delivered by contaminated site remediation programs. The results indicated the value of a statistical life (VSL) for an immediate risk reduction over the current year to be about $€ 5.6$ million.

Nevertheless, the changing patterns of urban development have recognized, since the mid-1980s, that brownfields should not be solely seen as a problem but also as an opportunity to foster the sustainable development of urban environment. Brownfields may be regenerated as commercial, residential or even industrial facilities in order to increase employment and economic growth, as well as to lessen the financial costs and risks associated with redevelopment. In addition, brownfields could be reclaimed as green areas, creating significant social and environmental benefits, for example air pollution control, noise attenuation, improvement of microclimate, provision of recreational opportunities, etc. [7], which are also connected with the economic viability of the surrounding area (e.g. [8-11]). 
Despite the existing potential, however, there are many obstacles opposing the brownfields redevelopment, the most important being the lack of the necessary resources especially under tight fiscal conditions. The situation is further complicated by the fact that the costs of redeveloping the derelict land can be assessed in a straightforward way but the benefits, in particular the environmental and social ones, are hard to estimate in monetary terms and they are often overlooked in decision-making processes. In order to confront with this situation, it is necessary to account for the benefits of regenerated brownfields in monetary terms by means of market and non-market valuation techniques.

This paper highlights the abovementioned issues through two illustrative case studies, namely the redevelopment of a former metallurgical complex to a Technological and Cultural Park and the potential transformation of the former Athens International Airport into a Metropolitan Park. Toward this direction, different approaches are applied to estimate the economic value generated by the redevelopment projects in order to justify the resources required to be spent.

\section{THE METALLURGY COMPLEX OF THE FORMER 'COMPAGNIE FRANCAISE DES MINES DU LAURIUM'}

\subsection{Site history and redevelopment}

The metallurgy complex of the former 'Compagnie Francaise des Mines du Laurium' is located adjacent to the city of Lavrion, about $55 \mathrm{~km}$ from the Athens metropolis. It occupies an area of approximately 25 hectares and comprises 41 stone-built buildings, including smelting facilities, storage areas, offices, etc. (Fig. 1).

The site holds a significant mining past related to the exploitation of the silver and lead ores, dating back to $3000 \mathrm{BC}$. Nevertheless, the systematic exploitation of the silver in particular took place in 508 BC [12]. During the Peloponnesian War, mining activity declined and in 413 BC the mines were closed. Some decades later, silver production started again with decreased rates though, until

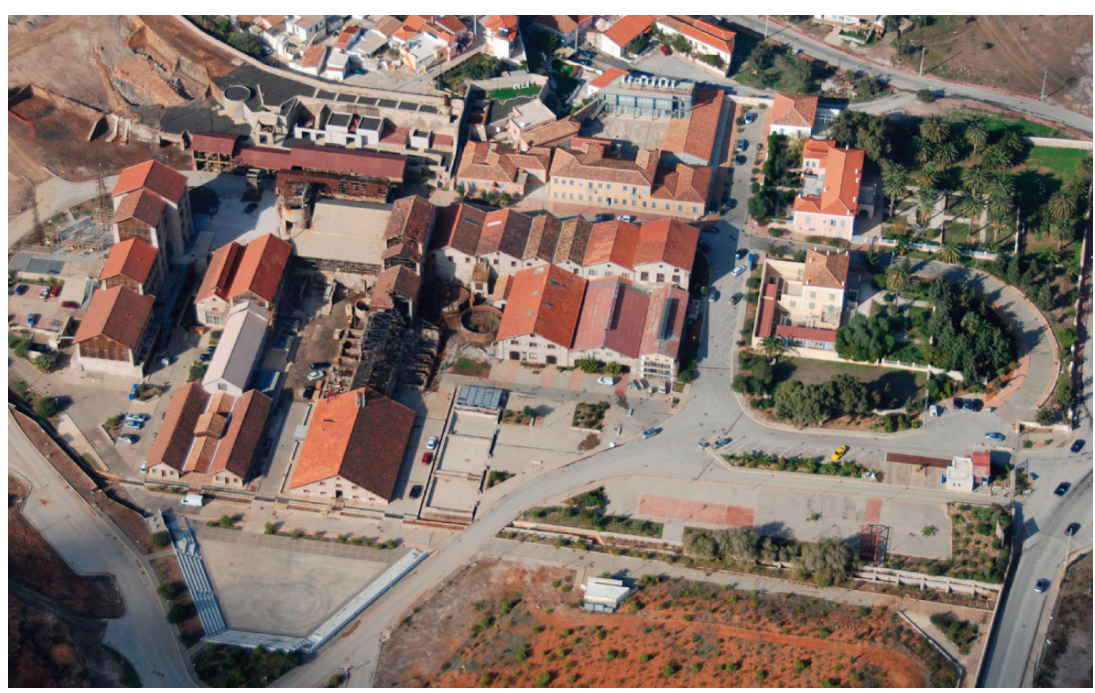

Figure 1: Aerial view of the metallurgical complex. Source: Lab of Mining and Environmental Technology, NTUA. 
the first Byzantine Period, 6th century AC. Between the 6th and 19th century any important mining and metallurgical activity at Lavrion ceased [13].

In the 19th century, the French company 'Hilarion Roux et Cia' undertook the exploitation of the ancient slags and the extraction of silver containing lead ores. After a dispute with the Greek State over the ownership of the ancient mining residues, two companies were founded in 1873, namely 'The Lavrion Metallurgical Company' and the French-Hellenic company named 'Mines du Camariza' [12]. The Greek company received the right to exploit the ancient ore residues, while the French-Hellenic company, led by the Italian mining engineer J.B. Serpieri, acquired the mining rights of the newly discovered ores [14]. Two years later, in 1875, Serpieri founded the most important industry in Greece at that period namely the French company 'Compagnie Francaise des Mines du Laurium', which succeeded the 'Mines du Camariza'. The Greek company operated until 1917, while the French company after a continuous operation for more than a century ceased permanently its industrial activities in the early 1990s [14].

The National Technical University of Athens (NTUA), recognizing the great architectural and aesthetical value of the buildings, the historical importance of the site and its strong potential for the regeneration of the entire area, which was suffering from high unemployment at the time, took the initiative to redevelop the site as a Technological and Cultural Park. In 1992, the site was assigned to the NTUA by the Ministry of Culture, after being sold by the French company to the Greek State and, in 1994, a funding program was approved to create the Lavrion Technological and Cultural Park (LTCP) [12]. The environmental site assessment, however, showed the presence of many heavy metals in the soil, which was characterized as unusually heavily contaminated. Therefore, a prerequisite for the realization of this vision was the solution of the environmental problem. After having partially restored the site and ensuring that the risk to human health had been eliminated, the Park started to operate. To date, fifteen buildings have been restored, some of which are already leased, whereas the rest of them are intended to accommodate administrative and cultural services.

\subsection{Regeneration value}

\subsubsection{Methodological approach}

In order to estimate the value generated by the redevelopment of the site under consideration, it is first necessary to recognize the actors involved, namely the 'Company for the Utilization and Management of the Property of the NTUA S.A. (CUMP-NTUA)', the NTUA, the Greek State and the European Union.

The LTCP operates as an individual legal entity of private right by the CUMP-NTUA. The sole share of the Company, which is indivisible and non-transferable, is owned by the NTUA [15]. The CUMP-NTUA supports the LTCP project through the employment of skilled personnel and the further development of the site. The latter is accomplished via funding projects and agreements with private companies that pay for the restoration of the buildings. As an offset, private companies pay only the $20 \%$ of the agreed monthly rent while the rest $80 \%$ is used to amortize the restoration cost during a predefined time period.

As regards the NTUA, it has provided a direct financial contribution of $\mathrm{k} € 60$, in 1996, in order to establish the CUMP-NTUA. Moreover, NTUA supports the LTCP by providing administrative and technical staff especially during construction periods. It is estimated that the cost of NTUA's personnel involved in the LTCP amounts annually to about $\mathrm{k} € 200$, on average.

Finally, the Greek State and the European Union funded the project through two Programs of the Greek Ministry of Development. The total amount of funding derived from both the EU (75\%) and national sources $(25 \%)$ was about $M € 23$. More specifically, in the middle of ' 90 s the project was 
funded by $\mathrm{M} € 15$ in order to restore buildings and contaminated land at an area of about $80,000 \mathrm{~m}^{2}$. In 2003, an additional amount of M€7.8 was approved to clean up more than $80,000 \mathrm{~m}^{2}$ of contaminated soil. Toward this direction, the environmental actions involved the excavation, transfer and disposal of the contaminated soil at an on-site watertight repository structure, the backfilling of the excavated areas with clean soil, the construction of an underground waste disposal facility and the establishment of an environmental laboratory.

Given the role and the objectives of the parties involved in the regeneration project, it is necessary to account for both financial and socio-economic benefits of the project. As far as the financial aspects are concerned, the analysis was carried out using a typical cash flow discounting-based company valuation method. For that purpose, past and future free cash flows of the CUMP-NTUA generated by the operation of the LTCP were taken into consideration, according to the following equation:

$$
\mathrm{V}=\frac{\mathrm{CF}_{1}}{(1+\mathrm{r})}+\frac{\mathrm{CF}_{2}}{(1+\mathrm{r})^{2}}+\frac{\mathrm{CF}_{3}}{(1+\mathrm{r})^{3}}+\ldots+\frac{\mathrm{CF}_{\mathrm{n}}+\mathrm{RV}}{(1+\mathrm{r})^{\mathrm{n}}}
$$

where $\mathrm{CF}_{\mathrm{i}}$ is the cash flow generated by the operation of the LTCP in the period $\mathrm{i}, \mathrm{RV}$ is the residual value of the facilities of LTCP in the year $n$ (assumed to be 0) and $r$ is the discount rate of the estimated cash flows.

In order to account for the socio-economic contribution of the project, the analysis was based on: (a) state revenues generated by direct and indirect taxes and (b) non-market benefits associated with the creation of direct employment and the remediation of the site. Tax gains were estimated by means of financial data provided by the Administration Office of the LTCP. The economic valuation of employment benefits followed the 'public expenditures approach'. This approach assumes that the economic value of increased employment, due to the realization of a project or policy, can be based on government's revealed willingness to pay in order to create one man-year of extra employment [16]. The rationale behind this assumption is that the government's willingness to pay to create extra employment reflects public preferences for employment increases, given that the government promotes and supports the public interest. Tourkolias et al. [17] estimated that the public expenditures for creating one man-year of employment in Greece ranges from $€ 4,000$ to $€ 12,000$, with a weighted average estimated at $€ 6,400$ per man-year of employment. The latter value was used in the context of this study for estimating the economic benefits of employment created by the redevelopment of the former metallurgy complex.

As regards the soil decontamination works, the remediation benefits were expressed in monetary terms by means of the 'replacement cost approach' according of which the cost of replacing or restoring a damaged environmental asset to its original state can be used as a measure of the benefit of restoration [18]. The monetary benefits of LTCP soil remediation works have been estimated by Karachaliou and Kaliampakos [19] through the development of a sophisticated method called ORFA, which stands for Optimum Remediation Funds Allocation. The basic concept of the ORFA method is to treat contaminated soil as a 'negative ore', offering the potential of using mining optimization tools under the theoretical framework of environmental economics. Finally, the value generated by the construction of the underground disposal facility was estimated through the 'substitute cost approach' (also known as 'alternative cost approach'), which refers to the least costly available substitute for the non-priced service or good under investigation [20]. In this context, the value of the underground waste repository was estimated as the saved cost of managing the waste by means of the least-cost alternative solution, that is using a specialized subcontractor to transfer the waste in a certified European disposal facility [21]. 


\subsubsection{Results}

Bearing in mind the social character of the LTCP, a real discount factor of 3\%, which is a commonly accepted social rate of discount [22], was used in order to estimate the present value of CUMP-NTUA's cash flows. The past cash flows derived from the CUMP-NTUA's income statements, while future cash flows were estimated on the basis of the following assumptions (in constant 2009 values):

- Total area of existing buildings allocated to the housing of businesses: $6,000 \mathrm{~m}^{2}$

- Total area of commercial plots: $18,000 \mathrm{~m}^{2}$, of which 4,000 $\mathrm{m}^{2}$ will be available for rent and the rest of them will accommodate new buildings with a total surface area of 7,000 $\mathrm{m}^{2}$

- Percentage of rental building space: $70 \%$

- Average monthly rental price for building complexes: $€ 10$ per $\mathrm{m}^{2}$

- Average annual rental price for commercial plots: $€ 15,000$ (for the total area of 4,000 $\mathrm{m}^{2}$ )

- Other revenues: $€ 50,000$ per annum

- Operating expenses: $85 \%$ of estimated earnings

- Tax rate: $25 \%$

- Concession period: 80 years

It should be noted that the assumptions adopted were conservative and were based on historical data provided by the LTCP Administration Office. According to the above figures, the present value of the commercial use of the site is estimated to be M€4.1.

Regarding the benefits to the Greek economy, the project has created tax revenues in excess of M€3.7 from the operation of the CUMP-NTUA and about M€6 from the hosted companies. Moreover, it is anticipated that the present value of future tax payments from the CUMP-NTUA will reach M€1.3. In addition, given that the number of employees in the LTCP and the hosted companies is about 110 , the direct employment benefits using the central value $€ 6,400$ per man-year of employment amount to $€ 700,000$ per year, which gives a present value of $\mathrm{M} € 21.1(\mathrm{r}=3 \%, \mathrm{n}=80$ years).

With respect to the environmental benefits, the net present economic value of soil remediation measures has been estimated to be $M € 24.8$ [19]. In order to estimate the benefits of the underground disposal facility on the basis of the 'alternative cost approach', the storage capacity of the facility (i.e. 5,000 tonnes) and the alternative waste management cost per tonne (i.e. $€ 1,500$ ) were taken into account [21]. According to these figures, the benefits of the underground waste disposal site, expressed as present value, are equal to M€7.5.

Bearing in mind that the total amount of funding in 2009 values is about M€36.7, the potential net benefits of site's redevelopment may be as high as M€31.4.

\section{THE FORMER ATHENS INTERNATIONAL AIRPORT SITE}

\subsection{Site history and redevelopment}

The former Athens International Airport, known as 'Hellenikon International Airport' is located $11.5 \mathrm{~km}$ south from the centre of Athens and was built in 1938. The site covers an area of $530 \mathrm{hec}-$ tares and borders residential areas, the Gulf of Saronikos and the Glyfada Golf Club (Fig. 2).

By the end of the 50s, the airport handled 500,000 passengers and 4,000 tonnes of cargo per year. These figures increased enormously in the next decades. In the early $70 \mathrm{~s}$, the airport handled $3,300,000$ passengers and 25,000 tonnes of cargo per year, while, in 1997, the number of passengers reached 12,000,000 and the cargo volume handled was 120,000 tonnes. Given that the airport could 


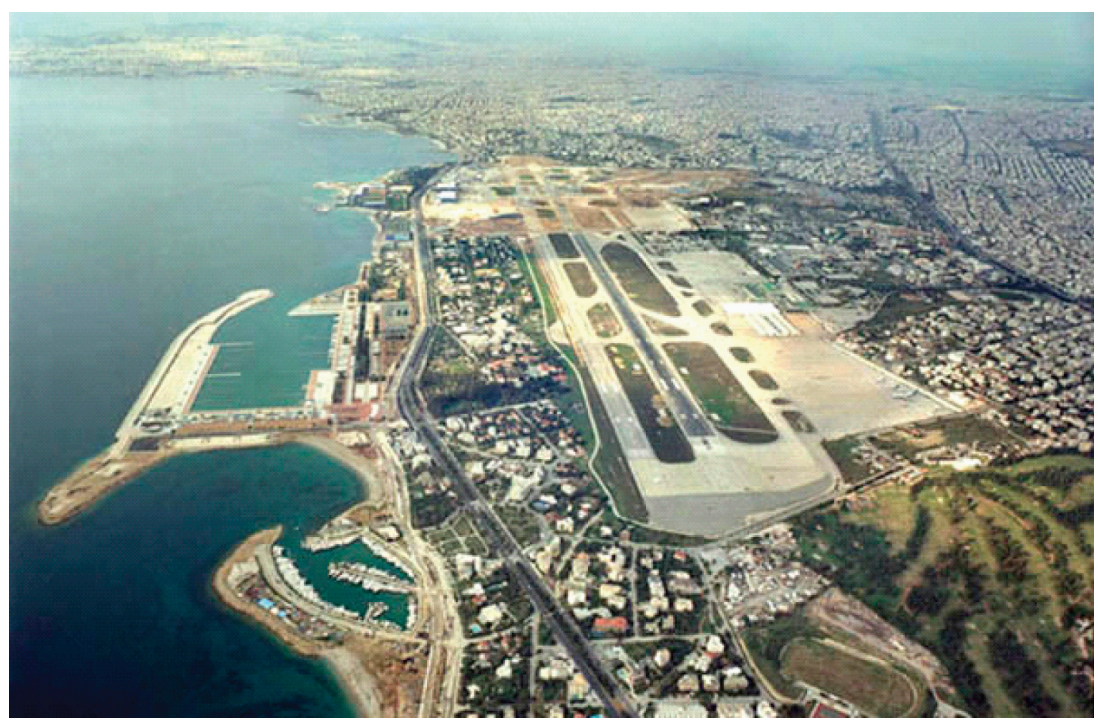

Figure 2: The former Athens International Airport. Source: SERERO Architects.

not meet future demand since the surrounding residential area prohibited any further expansion, it was decided to relocate the airport. In March 2001, after an uninterrupted operation of 60 years, the Athens International Airport was finally moved to a new location, at Spata, where the new 'Eleftherios Venizelos' Airport was built [23].

The area includes 419 buildings, of which 126 belong to the Civil Aviation Authority. Although the northern and western portions of the site have changed, the Athens radar center and part of the old airport and its runways still exist at an area of about 300 hectares. Since the termination of operations of Hellenikon International Airport and especially after the 2004 Summer Olympics, there have been discussions concerning the reuse of airport's facilities. A part of the area was redeveloped and hosted the venues for basketball, fencing, canoe/kayak slalom, field hockey, baseball and softball during the 2004 Summer Olympics. Today, the Hellenikon Complex, comprising six sport grounds and two training facilities, covers an area of about 80 hectares and is managed by the Hellenic Olympic Properties S.A., a state-owned enterprise. An area of about 20 hectares is administered by the Hellenic Tourism Development Co., a state-owned enterprise, as well. Finally, an area of about 11 hectares is used as tram and bus depot and 5.5 hectares have been given away to local entities.

In June 2006, the Greek Minister for the Environment, Physical Planning and Public Works announced a final draft plan known as Hellenikon Metropolitan Park, according to which 400 hectares will be converted to a park, while 100 hectares will be used to accommodate housing and office facilities. The proposed plan is envisaged to create the largest urban park in Europe that will enhance the standards of living conditions of Athens' inhabitants. In total, green areas and amenity spaces will exceed 550 hectares, given that the plan also foresees the connection of the park with the beachfront and the demolition of 378 out of the 419 buildings of the old airport. The plan, as mentioned, involves a business zone of 65 hectares and a residential zone of 35 hectares, respectively, as well as a new museum of modern art. The built-up areas will cover 26 hectares, while the rest surface will be provided for public/common uses and infrastructure. The Greek State estimates that selling this area to land developers will provide revenues of M€500, an amount sufficient enough for funding the 
Hellenikon Metropolitan Park project (the estimated cost for the park ranges between $k € 760$ and $\mathrm{k} € 1,000$ per hectare) and smaller parks in devastated areas of Athens.

However, representatives from the surrounding municipalities (namely Alimos, Argyroupoli, Glyfada and Hellenikon) and other entities argued that the proposed plan will create a new city with a population of 15,000-20,000 people. Thus, they counter proposed an alternative plan involving solely the development of a green park with light recreational facilities, which establishes additionally 30-100 hectares of green space (depending on the final design of the built area proposed by the first plan). In support of this proposal, the Local Union of Municipalities and Town Councils of Attica (LUMTCA) assigned a research project to the Urban Environment Laboratory (UEL) of NTUA [24]. The UEL research team estimated that the redevelopment of the former airport as a park could be achieved at a cost of $k € 100$ and $k € 150$ per hectare (i.e. a total cost between M€50 and $\mathrm{M} € 100)$, as indicated by relevant projects, for example the redevelopment of the Maurice Rose Airfield in Frankfurt.

Damigos and Laliotis [25] evaluated the two alternatives considering the effect of the proposed plans to the property prices in the surrounding area. Given the scope and the objectives of the present study, the analysis hereinafter focuses solely on the monetization of the municipalities' proposal.

\subsection{Regeneration value}

\subsubsection{Methodological approach}

A systematic effort to quantify the benefits of urban forests in monetary terms is being carried out during the last three decades, although attempts to measure the economic value of urban open space have taken place since 1930 [26]. Toward this direction, a number of approaches have been applied, such as the fiscal impact analysis (also known as cost-revenue analysis) (e.g. [27]), the contingent valuation method (e.g. [8, 28, 29]) and the hedonic pricing method (e.g. [30, 31]). Nevertheless, there has been a continuous debate concerning theoretical and practical issues of the above-mentioned techniques, in particular the use of the hedonic pricing and the contingent valuation methods. For example, the application of the hedonic method prerequisites the availability of extensive data in order to isolate the contribution of the environmental factor to the market price by means of econometric techniques that should be collected from a reasonably stable market period. Additional issues may arise with respect to econometric model specification and level of disaggregation, market distortions, etc. (e.g. [32, 33]). Finally, it should be mentioned that the method cannot be easily applied when potential changes on the environmental quality are investigated, thus it is mainly used in ex-post analyses. Yet, a detailed analysis of those criticisms is beyond the scope of this paper.

Bearing in mind the above remarks, an alternative approach was applied in order to estimate the monetary benefits of redeveloping the former Athens International Airport to a green park with only light recreational facilities, namely the Fuzzy Delphi Method (FDM). The FDM is an analytical process based on the Delphi Method [34, 35] and is actually an expert judgment method that involves a structured process for the systematic collection and collation of judgments from a group of experts by means of a series of questionnaires interspersed with controlled opinion feedback [36]. The FDM, which is based on the theory of fuzzy sets, was adopted instead of the simple Delphi in order to deal with the effect of subjectivity of the experts, as well as the uncertainty imposed by the complexity of the problem.

Fuzzy sets are an extension of the classical set theory [37]. A fuzzy set is characterized by a membership-degree function, which maps the members of the Universe into the unit interval $[0 ; 1]$. 
The value 0 means that the member is not included in the given set, 1 describes a fully included member. Hence, for the universe $\mathbf{U}$ a fuzzy set $\mathbf{A}$ is defined by:

$$
\left.\mathrm{A}=\left\{\mathrm{x}, \mu_{\mathrm{A}}(\mathrm{x})\right) \mid \mathrm{x} \in \mathrm{A}, \mu_{\mathrm{A}}(\mathrm{x}) \in 0,1\right\}
$$

where $\mu_{\mathrm{A}}(\mathrm{x})$ is the membership-degree function $\mu: \mathrm{x} \rightarrow[0 ; 1]$.

A fuzzy number is defined in the universe $\mathbf{R}$ as a convex and normalized fuzzy set. In this case, the triangular numbers were considered to be mostly suitable, since they could be constructed easily by asking the experts to specify three values, the minimum, the maximum and the most plausible. More specifically, the triangulated fuzzy number $\mathbf{T}$ with membership function $\mu_{\mathrm{A}}(\mathrm{x})$ is defined on $\mathbf{R}$, as follows:

$$
\mathrm{T}=\left\{\begin{array}{c}
\mathrm{x}-\mathrm{a} / \mathrm{b}-\mathrm{a} \\
\mathrm{x}-\mathrm{c} / \mathrm{b}-\mathrm{c} \\
0
\end{array}\right\} \begin{aligned}
& \mathrm{a} \leq \mathrm{x} \leq \mathrm{b} \\
& \mathrm{b} \leq \mathrm{x} \leq \mathrm{c} \\
& \text { otherwise }
\end{aligned}
$$

where $[\mathbf{a}, \mathbf{c}]$ is the supporting interval and the point $(\mathbf{b}, \mathbf{1})$ is the peak.

The FDM consists of the following steps [38]:

Step 1. The experts $E_{i}, i=1,2, \ldots, n$, are asked to provide their estimates on the particular subject, determining the minimum $\alpha_{1}{ }^{(i)}$, the most plausible $a_{M}{ }^{(i)}$ and the maximum $a_{2}{ }^{(i)}$. The data given by the experts $\mathrm{E}_{\mathrm{i}}$ are presented in the form of triangular numbers:

$$
A_{i}=\left(a_{1}{ }^{(i)}, a_{M}{ }^{(i)}, a_{2}{ }^{(i)}\right), i=1,2, \ldots, n
$$

Step 2. The fuzzy average $A_{\text {ave }}=\left(m_{1}, m_{M}, m_{2}\right)$ of all $A_{i}$ is estimated, according to the equation:

$$
\mathrm{A}_{\text {ave }}=\left(\mathrm{m}_{1}, \mathrm{~m}_{\mathrm{M}}, \mathrm{m}_{2}\right)=\left(\frac{1}{\mathrm{n}} \sum_{\mathrm{i}=1}^{\mathrm{n}} \mathrm{a}_{1}{ }^{(\mathrm{i})}, \frac{1}{\mathrm{n}} \sum_{\mathrm{i}=1}^{\mathrm{n}} \mathrm{a}_{\mathrm{m}}{ }^{(i)}, \frac{1}{\mathrm{n}} \sum_{\mathrm{i}=1}^{n} \mathrm{a}_{2}{ }^{(\mathrm{i})}\right)
$$

Next, for each expert the deviation between $\mathrm{A}_{\text {ave }}$ and $\mathrm{A}_{\mathrm{i}}$, is computed, which is a triangular number defined by:

$$
\mathrm{A}_{\mathrm{ave}}-\mathrm{A}_{\mathrm{i}}=\left(\mathrm{m}_{1}-\mathrm{a}_{1}{ }^{(\mathrm{i})}, \mathrm{m}_{\mathrm{M}}-\mathrm{a}_{\mathrm{M}}{ }^{(\mathrm{i})}, \mathrm{m}_{2}-\mathrm{a}_{2}{ }^{(\mathrm{i})}\right)=\left(\frac{1}{\mathrm{n}} \sum_{\mathrm{i}=1}^{\mathrm{n}} \mathrm{a}_{1}{ }^{(\mathrm{i})}-\mathrm{a}_{1}{ }^{(\mathrm{i})}, \frac{1}{\mathrm{n}} \sum_{\mathrm{i}=1}^{\mathrm{n}} \mathrm{a}_{\mathrm{m}}{ }^{(\mathrm{i})}-\mathrm{a}_{\mathrm{m}}{ }^{(\mathrm{i})}, \frac{1}{\mathrm{n}} \sum_{\mathrm{i}=1}^{\mathrm{n}} \mathrm{a}_{2}{ }^{(\mathrm{i})}-\mathrm{a}_{2}{ }^{(\mathrm{i})}\right)
$$

The deviation $\mathrm{A}_{\mathrm{ave}}-\mathrm{A}_{\mathrm{i}}$ is given back to the experts for revision.

Step 3. Each expert $E_{i}$ gives a new triangular number:

$$
\mathrm{B}_{\mathrm{i}}=\left(\mathrm{b}_{1}{ }^{(\mathrm{i})}, \mathrm{b}_{\mathrm{M}}{ }^{(\mathrm{i})}, \mathrm{b}_{2}{ }^{(\mathrm{i})}\right), \mathrm{i}=1,2, \ldots, \mathrm{n}(7)
$$

The experts are requested to give their opinion separately and independently about the variables in question. The results of the first round are analyzed statistically by finding their average and are then interspersed to the participants, who are asked if they wish to revise their earlier estimates. This process, starting with step 2 , is followed again and again until the outcome converges to a reasonable solution from the point of view of the decision maker.

The Delphi approach has been criticized for dependency of forecasts on the particular judges selected, the sensitivity of results to ambiguity in the questionnaire and the difficulty in assessing the degree of expertise incorporated into the forecast (e.g. [39]). Nevertheless, several studies indicate high agreement between the Delphi estimates and the real numbers (e.g. [40]). 


\subsubsection{Survey characteristics}

A panel consisting of 10 real-estate experts was employed taking into consideration the participants' background in terms of professional skills and experience so as to maximize the effectiveness of the study. Furthermore, panelists were provided with guidelines to increase the reliability of their answers and they were told that they were free to add their comments.

The experts were provided with a specially formed questionnaire, in order to give their estimates for the effect of each redevelopment alternative on the price of dwellings located in the vicinity. The questionnaire consisted of a comprehensive list of 28 questions. The first set included questions regarding the effect of the airport, while it was operating. The second set referred to the influence of the termination of operations of the Hellenikon Airport on the surrounding housing market, while the third set of questions investigated the 'true' effect of the announcement of airport's development. The answers given by the experts regarding the questions of the first three sets derived from market data. The final set of questions focused on the proposed plans. The panelists were asked to forecast the effects of each of the proposed alternatives on the housing market of the neighboring area with respect to the zone of influence of each alternative on the dwelling price (in $\mathrm{km}$ ) and the premium attracted by a typical dwelling located in the zone of influence (in percentage). As mentioned, only the results referred to the municipalities' proposal are discussed in the next section.

\subsubsection{Results}

The survey was completed in two rounds, since the point of diminishing returns was considered to be satisfying. For conciseness reasons, only the results of the second round are presented.

According to the results, the Park is expected to affect the dwelling prices at a range up to $3 \mathrm{~km}$ (Table 1). A dwelling within this zone is envisaged to attract, on average, a premium of $21-52 \%$, with the most probable rate being $36 \%$ (Table 2). Given that in the year 2006, the average unit price of a dwelling in the area of interest was $€ 3,000$ per $^{2}$, the added value to the neighboring properties is estimated to $€ 1,080$ per $\mathrm{m}^{2}$, which in turn results in a premium of $€ 108,000$ for a typical apartment

Table 1: Influence zone (IZ) (in km).

\begin{tabular}{lccc}
\hline $\mathrm{E}_{\mathrm{i}}$ & $\mathrm{IZ}_{\text {min }}$ & $\mathrm{IZ}_{\text {likely }}$ & $\mathrm{IZ}_{\max }$ \\
\hline $\mathrm{E}$ 1 & 0 & 1 & 2 \\
$\mathrm{E} 2$ & 0 & 2 & 3 \\
$\mathrm{E} 3$ & 0 & 2 & 3 \\
$\mathrm{E} 4$ & 0 & 1 & 2 \\
$\mathrm{E} 5$ & 0 & 2 & 2 \\
$\mathrm{E} 6$ & 0 & 2 & 2 \\
$\mathrm{E} 7$ & 0 & 1 & 2 \\
$\mathrm{E} 8$ & 1 & 2 & 3 \\
$\mathrm{E} 9$ & 0 & 1 & 2 \\
$\mathrm{E} 10$ & 0 & 1 & 2 \\
Average & 0 & 2 & 3 \\
Minimum & 0 & 1 & 2 \\
Maximum & 1 & 2 & 3 \\
\hline
\end{tabular}


Table 2: Price alteration (PA) (in percentage).

\begin{tabular}{lccc}
\hline $\mathrm{E}_{\mathrm{i}}$ & $\mathrm{PA}_{\min }$ & $\mathrm{PA}_{\text {likely }}$ & $\mathrm{PA}_{\max }$ \\
\hline $\mathrm{E} 1$ & 15 & 35 & 50 \\
$\mathrm{E} 2$ & 25 & 35 & 60 \\
$\mathrm{E} 3$ & 25 & 30 & 40 \\
$\mathrm{E} 4$ & 20 & 30 & 40 \\
$\mathrm{E} 5$ & 20 & 50 & 70 \\
$\mathrm{E} 6$ & 15 & 30 & 50 \\
$\mathrm{E} 7$ & 20 & 30 & 50 \\
$\mathrm{E} 8$ & 20 & 35 & 40 \\
$\mathrm{E} 9$ & 20 & 40 & 60 \\
$\mathrm{E} 10$ & 25 & 40 & 60 \\
Average & $21 \%$ & $36 \%$ & $52 \%$ \\
Minimum & $15 \%$ & $30 \%$ & $40 \%$ \\
Maximum & $25 \%$ & $50 \%$ & $70 \%$ \\
\hline
\end{tabular}

in the surroundings (average saleable area: $100 \mathrm{~m}^{2}$ ). Taking into account that the implementation cost of the proposed plan lies between M€50 and M€100, if the Park influences 1,000 apartments in the surrounding area (which is possible), it will produce enough value to cover the redevelopment cost. Off course, it should be considered that this added value could be detached only by means of a special property tax in a depth of time.

The economic benefits of the Park are not restricted to the increase in the surrounding property value. Energy savings of buildings due to the impact of the Park to the microclimate or air pollution reductions could also be significant. For example, the US studies estimated that a park in Chicago provided air pollution reductions equivalent to traditional emissions controls costing US $\$ 136$ per day [41], while savings on cooling costs for a typical household, in general, ranged between 1.9 and $2.5 \%$ per residential tree [42]. In addition to those findings, the Center for Urban Forest Research of the USDA Forest Service estimated that the per tree average annual net benefits of energy savings, reduced atmospheric carbon dioxide, improved air quality, reduced stormwater runoff and aesthetics were US\$1-8 for a small tree up to US\$48-53 for a large tree [43]. Finally, several contingent valuation studies indicate significant use and non-use values associated with urban forests. In the city of Athens, in particular, a recent study indicated that households were willing to pay an annual fee of $€ 41.5$ in order to establish a forestry organization for maintaining and enhancing city's green spaces [44].

\section{CONCLUSIONS}

Brownfields regeneration is an established trend in the modern world. Nevertheless, the redevelopment of brownfields is, first of all, an economic puzzle, and the lack of the necessary funds for dealing with the problem calls for a clear and sound answer with respect to the net social benefits gained. Toward this direction, the decision-making process should take into consideration both market and non-market benefits (with the latter being more difficult to estimate, although the relative methodologies are improving continuously) in order to come up with more fair and justified solutions. The monetization of environmental and social costs and benefits, particularly, may reveal 
latent economic aspects and, thus, provide the means to evaluate a redevelopment project not only according to its financial profitability but also on its performance toward sustainable development, in general.

The use of the most appropriate method depends on the particular characteristics of each case, namely the proposed land use to be established (i.e. social or commercial), the actors involved (e.g. public or private investors) and, if any, the contamination problem solved. For instance, commercial redevelopment of brownfields sites by private investors should be evaluated on the grounds of private investment criteria, such as the Internal Rate of Return and the Net Present Value of the project. On the other hand, brownfields reclaimed for community non-profit use (e.g. green areas) using public funds could only prove their viability by monetizing non-market benefits via environmental valuation techniques. In some cases, private and social evaluation tools need to be combined to best aid decision-makers. The latter was quite clear in both cases presented.

In the case of LTCP, the financial benefits of the project derived from the commercial exploitation of the site were estimated to be M€4.1, whereas the cost of restoring the site, so far, exceeds M€36 (in 2009 prices). Therefore, from a financial point of view the project should have been rejected. However, the monetization of the socio-economic and environmental benefits of the project (e.g. tax revenues, employment, ecosystem restoration, etc.) provides a present value of M€64, which results in a potential net benefit of M€31.

As far as the case of Hellenikon Metropolitan Park is concerned, the results prove that even a 'pure' green area would create significant economic value for the society, which is capitalized in the value of the surrounding properties. Ignoring this value, the commercialization of the site would be deemed as the only viable solution and the park would be subjected to development pressure. The identification and quantification of the non-financial benefits of the park in monetary terms provides at least the opportunity for developing a more transparent and socially fair decision-making analysis.

\section{REFERENCES}

[1] Oliver, L., Ferber, U., Grimski, D., Millar, K. \& Nathanail, P., The Scale and Nature of European Brownfields, in: Oliver L, Millar K, Grimski D, Ferber U, Nathanail P., Proc. of CABERNET 2005: The International Conference on Managing Urban Land, Land Quality Press, Nottingham, UK, pp. 274-281, 2005.

[2] Spector, K. and Manson, C., Appendix A - Review of Current Property Valuation Literature, Memorandum to J. Schumann, US EPA OSWER, Industrial Economics, Inc., 1999, http://www.epa.gov/oswer/docs/ustdocs/appendic.pdf

[3] Thayer, M., Albers, H., Rahmatian, M., The benefits of reducing exposure to waste disposal sites: a hedonic housing value approach. Journal of Real Estate Research, 7(3), pp. 265-282, 1992.

[4] Farber, S., Undesirable facilities and property values: a summary of empirical studies. Ecological Economics, 24(1), pp. 1-14, 1998. doi: http://dx.doi.org/10.1016/S0921-8009(97)00038-4

[5] McCluskey, J.J. \& Rausser, G.C., Estimation of perceived risk and its effect on property values. Land Economics, 77(1), pp. 42-55, 2001. doi: http://dx.doi.org/10.2307/3146979

[6] Alberini, A., Tonin, S. Turvani, M. \& Chiabai, A., Paying for Permanence: Public Preferences for Contaminated Site Cleanup, Journal of Risk and Uncertainty, 34(2), pp. 155-178, 2007. doi: http://dx.doi.org/10.1007/s11166-007-9007-8

[7] Commission of the European Communities (CEC), Green Paper on the Urban Environment, COM(90) 218 Final, Brussels, 27 June, 1990.

[8] Tyrväinen, L. \& Väänänen, H., The economic value of urban forest amenities: an application of the contingent valuation method, Landscape and Urban Planning. 43(1-3), pp. 105-118, 1998. doi: http://dx.doi.org/10.1016/S0169-2046(98)00103-0 
[9] Damigos, D. \& Kaliampakos, D., Assessing the benefits of reclaiming urban quarries: a CVM analysis, Landscape and Urban Planning, 64(4), pp. 249-258, 2003. doi: http://dx.doi. org/10.1016/S0169-2046(02)00243-8

[10] Damigos, D. \& Kaliampakos, D., Forecasting the effects of environmental changes on residential land prices: An application of Fuzzy Delphi Method, Thirteenth Annual Conference of EAERE, June 25-28th, Budapest, Hungary, 2004.

[11] Nowak, D.J. \& Dwyer, J.F., Understanding the benefits and costs of urban forest ecosystems. Urban and community forestry in the Northeast, 2nd edition, ed. Kuser, J., Springer, the Netherlands, pp. 25-46, 2007.

[12] Lavrion Technological and Cultural Park, Mining at Lavrio in the 19th and the 20th Century, http://www.ltp.ntua.gr/lavrion_park/history_en

[13] Lavrion Minerals, History of Lavrion mines, http://www.lavrionminerals.com/index.php? option=com_content \&view $=$ article $\&$ id $=23 \&$ Itemid $=29$

[14] Markouli-Bodioti, A., The creation and evolution of the "Compagnie Francaise des Mines du Laurium" fosters new developments in the economic and industrial sectors of Greek Society of the 19th and 20th Century, PhD Thesis, National Technical University of Athens, Athens, Greece, 2007. (in Greek)

[15] Lavrion Technological and Cultural Park, Administration, http://www.ltp.ntua.gr/lavrion_park/ administration_en

[16] European Commission, ExternE: externalities of energy - Vol. 6 Wind \& Hydro, European Commission, DG XII, Brussels, 1995.

[17] Tourkolias, C., Mirasgedis, S., Damigos, D., \& Diakoulaki, D., Employment benefits of electricity generation: A comparative assessment of lignite and natural gas power plants in Greece, Energy Policy, 37(10), pp. 4155-4166, 2009. doi: http://dx.doi.org/10.1016/j.enpol.2009.05.015

[18] Pearce, D. \& Howarth, A., Technical Report on Methodology: Cost Benefit Analysis and Policy Responses, RIVM report 481505020, National Institute of Public Health and the Environment, 2000.

[19] Karachaliou, T. \& Kaliampakos, D., ORFA: introducing a method for maximizing social profit from soil remediation funds, Journal of Soils and Sediments, Section 3: Remediation and Management of Contaminated or Degraded Lands, DOI 10.1007/s11368-010-0288-1, 2010.

[20] Markandya, A., Harou, P., Bellù L. G. \& Cistulli, V., Environmental Economis for Sustainable Growth: A Handbook for Practitioners, Edward Elgar. Chelthenam, UK, 2002.

[21] Kaliampakos, D. \& Benardos, A., Developing the first underground hazardous waste repository in Greece, Proc. 3rd AMIREG International Conference Assessing the Footprint of Resource Utilization and Hazardous Waste Management, 7-9 September, Athens, Greece, 2009.

[22] Girola, J., The long-term real interest rate for social security, Research Paper No. 2005-02, US Department of Treasury, 2005.

[23] Air Traffic Safety Electronic Engineers Association of Hellenic Civil Aviation Authority, Athens International Airport History, http://www.hcaa-eleng.gr/athhist.htm\#English

[24] Urban Environment Laboratory, Metropolitan Park of High Green at the Former Athens International Airport, School of Architecture, National Technical University of Athens, http:// courses.arch.ntua.gr/el/ergastirio_astikoy_periballontos/ereynhtika_programmata/29_mhtropolitiko_parko_ychloy_prasinoy_sto_prvhn_aerodromio_ellhnikoy_2010.html (in Greek)

[25] Damigos, D. \& Laliotis, E., Estimating the economic benefits of redeveloping the former Athens International Airport, 3rd International Conference on Environmental Economics and Investment Assessment, eds K. Aravossis \& C.A. Brebbia, WIT Press: Southampton, pp. 39-50, 2010. doi: http://dx.doi.org/10.2495/EEIA100041 
[26] Burchell, R.W. \& D. Listokin, Fiscal Impact Procedures and the State of the Art: The Subset Question of the Costs and Revenues of Open Space and Agricultural Lands, Rutgers University Center for Urban Policy Research, New Brunswick, NJ. Presented at "Does Land Conservation Pay? Determining the Fiscal Implications of Preserving Open Land", Cambridge, MA: Lincoln Institute of Land Policy, 1992.

[27] Fausold, C. \& Lilieholm, R.J., The Economic Value of Open Space: A Review and Synthesis, Lincoln Institute of Land Policy, Lincoln Institute, Research Paper WP96CF1, 1996.

[28] Treiman, T. \& Gartner, J., What do people want from their community forests? Results of a public attitude survey in Missouri US. Journal of Arboriculture, 31(5), pp. 243-250, 2005.

[29] del Saz Salazar, S. \& Menéndez, G., Estimating the non-market benefits of an urban park: Does proximity matter? Land Use Policy, 24(1), pp. 296-305, 2007. doi: http://dx.doi.org/10.1016/j. landusepol.2005.05.011

[30] Tyrvainen, L. \& Miettinen, A., Property prices and urban forest amenitie., Journal of Environmental Economics and management, 39(2), pp. 205-233, 2000. doi: http://dx.doi.org/10.1006/ jeem.1999.1097

[31] Laverne, R.J. \& Winson-Geideman, K., The influence of trees and landscaping on rental rates at office buildings. Journal of Arboriculture, 29(5), pp. 281-290, 2003.

[32] Butler, R.V., The specification of housing indexes for urban housing. Land economics, 58, pp. 96-108, 1982. doi: http://dx.doi.org/10.2307/3146079

[33] Palmquist, R.B., Hedonic methods. Measuring the demand for environmental quality, eds J.B. Braden, \& C.D. Kolstad, North-Holland, Amsterdam, pp. 77-120, 1991.

[34] Dalkey, N. \& Helmer, O., An Experimental Application of the Delphi Method to the Use of Experts, Management Science, 9(3), pp. 458-467, 1963. doi: http://dx.doi.org/10.1287/mnsc.9.3.458

[35] Dalkey, N., The Delphi Method: An Experimental Study of Group Opinion, RM-5888-PR, The RAND Corporation, Santa Monica, California, USA, 1969.

[36] Adler, M. \& Ziglio, E., Gazing into the Oracle: The Delphi Method and its Application to Social Policy and Public Health, Philadelphia: Taylor and Francis, pp. 264, 1996.

[37] Kaufman, A. \& Gupta, M.M., Fuzzy Mathematical Models in Engineering and Management Sciences, North-Holland, Amsterdam, 1988.

[38] Bojadziev, G. \& Bojadziev, M., Fuzzy Logic for Business, Finance and Management, Word Scientific Publishing: Singapore, 232 p., 1997.

[39] Madridakis, S. \& Wheelwright, S.C., Interactive Forecasting, Univariate and Multivariate Methods, Second Edition. Holden-Day. San Francisco, 1978.

[40] Milkovich, G., Anthony A. \& Thomas M., The Use of Delphi Procedures in Manpower Forecasting, Management Science, 19(4), pp. 381-388, 1972. doi: http://dx.doi.org/10.1287/ mnsc.19.4.381

[41] McPherson, E.G., Environmental benefits and costs of the urban forest, Proc. of the 5th National Urban Forest Conf., ed. Rodbell, American Forestry Association: Washington DC., pp. 52-54, 1992.

[42] Simpson, E.G. \& McPherson, J.R., Simulation of Tree Shade Impacts on Residential Energy Use for Space Conditioning in Sacramento. Atmospheric Environment, 32(1), pp. 69-74, 1998. doi: http://dx.doi.org/10.1016/S1352-2310(97)00181-7

[43] Wolf, K.L., What Could We Lose? Economic Values of Urban Forest Benefits, In: Kenney, A. (ed.) Proceedings of the 6th Canadian Urban Forest Conference, Ottawa, Ontario, Tree Canada Foundation, 2004, http://www.naturewithin.info/Policy/EconCnda.pdf.

[44] Kalavrytinos, N. \& Damigos, D., The Economic Value of Urban Green Spaces in the Attica Basin, Technica Chronica Scientific Journal, Technical Chamber of Greece, 2(1-2), pp. 7-21, 2006. 